\title{
1990 Von Hippel Award Nominations Sought
}

MRS Awards Committee Chair J. Murray Gibson has announced that nominations are being accepted for the Society's highest honor, the Von Hippel Award.

The Von Hippel Award is an international hallmark of excellence and distinction in the field of materials research. It was named in honor of Emeritus Professor of the Massachusetts Institute of Technology, Arthur von Hippel, whose laboratory pioneered the collaborative, interdisciplinary investigation that has come to be identified as "materials research."

The Award recognizes those qualities most prized by materials scientists and engineers-brilliance and originality of intellect combined with vision that transcends the boundaries of conventional scientific disciplines. The Award is presented at the MRS Fall Meeting.

The recipient is selected by majority vote of the MRS Council from a slate of candidates prepared by the Awards Committee. Previous recipients include: Prof. Authur von Hippel, Dr. William O. Baker, Prof. David Turnbull, Prof. W. Conyers Herring Prof. James W. Mayer, Prof. Clarence M. Zener, Prof. Sir Peter B. Hirsch, Dr. Walter L. Brown, Dr. John W. Cahn, Prof. Minko Balkanski, Sir Charles Frank, Prof. Jacques
Friedel, and Prof. John B. Goodenough.

Nominations can be prepared using the form on p. 78 in this issue. (Additional forms are obtainable from MRS Headquarters.) The form describes the award criteria and includes instructions for preparing the nomination. Names placed in nomination are, in accord with MRS Bylaws, considered active for three years. Completed nominations packages are due July 1, 1990 and should be sent to: J. Murray Gibson, MRS Awards Committee Chair, AT\&T Bell Laboratories, Room 1E-234, 600 Mountain Avenue, Murray Hill, NJ 07974.

\section{MRS Offers Major New Awards}

\section{Outstanding Young Investigator Award and MRS Medal Debut in 1990}

The MRS Awards Committee has announced the establishment of two new prestigious awards for excellence in materials research. The Outstanding Young Investigator Award and MRS Medal reflect the desire of the Materials Research Society to make meaningful public recognition of those individuals whose research is, in a variety of special ways, making major and dynamic contributions to the advancement of materials fields. "These awards add important new dimensions to our program," says John Baglin (1989 Awards Committee Chair). "The Young Investigator Award is intended to recognize exceptional future promise in a dynamic research career. An MRS Medal will be a hallmark recognizing a recent major scientific or technical achievement or breakthrough in a materials-related area."

"These awards will be accessible to outstanding people, regardless of their particular materials field of work," he emphasized. "Recipients will be researchers displaying only the highest quality of achievement; it is our intent that these awards will earn recognition and prestige on the basis of such high standards."

Together with the Von Hippel Award, the Medal and the Young Investigator Award will represent the highest distinctions that MRS can confer for brilliant materials research. In addition to professional recognition, each carries a substantial cash prize and an engraved medal or citation plaque. MRS Medals (two will be awarded in 1990) will be formally presented at an MRS meeting, and each medalist will be invited to give a brief technical talk. The Young Investigator Award will be given at the MRS Spring Meeting each year, where the recipient will also be asked to speak.

The new awards are to be supported by a new MRS Awards Endowment Fund, whose yield can fully sustain the awards and whose existence will ensure the stability of these ongoing programs. Major contributions to constitute this self-sustaining fund are being solicited this year by the Society. L. Michael Quick, Presidential Adviser on MRS Development, will coordinate this project.

\section{Excellence, Innovation, Enterprise}

Excellence remains the key criterion for the entire MRS Awards Program, while the new awards will serve to extend its diversity. Innovation and enterprise, marked by the successful use of the interdisciplinary approach to materials research, will continue to be the principal theme of the program. "We see the new, enhanced Awards Program not only as a means of honoring great achievement," said Baglin, "but also as a means of encouraging younger researchers whose efforts will shape the future of the materials field. These premier awards will also help us to highlight the most significant new discoveries (and their authors), and increase their visibility and recognition, both within the technical community and in the strategic communities of education, business and government."

The MRS awards program features:

- The Von Hippel Award, the Society's highest award, is described above.

- The Outstanding Young Investigator Award, recognizing a person aged 35 or under whose excellent interdisciplinary materials research indicates exceptional promise for future leadership in this field.

- The MRS Medal, recognizing a recent major pioneering research achievement in any materials-related field.

- Graduate Student Awards, recognizing outstanding graduate research presented at an MRS meeting. Students must be authors or co-authors of a paper. Finalists, selected on the basis of technical quality and references, present their papers to a panel of judges. Winners are judged for both content and quality of presentation.

\section{Nomination Procedures}

Now is the time to nominate a candidate for a 1990 MRS award! The requirements are simple: quality and brevity are the key attributes of an effective nomination package. The Awards Committee welcomes nominations for all the awards and strongly urges you to participate.

Von Hippel Award nominations, which can be prepared using the form on p. 78, are due July 1 . Nominations for the MRS Medalist Program are also due July 1 . The nomination deadline for the Outstanding Young Investigator Award, to be presented for the first time during the 1991 Spring Meeting, is November 1, 1990, but nominations are welcome before that date. Graduate Student Award applications for the 1990 Fall Meeting should be submitted to John B. Ballance, Executive Director, Materials Research Society, by September 1, 1990. Application forms and instructions are available from MRS Headquarters.

MRS is pleased to offer this Awards Program as a celebration of the excellence which truly underlies the spectacular progress of materials research today. MाR 


\section{MRS MEDALIST PROGRAM}

\section{PUAPOSE}

To constitute public and protessional recognition of outstanding recent achioverments in materiais research. A Medal will be awerded for a specific discovery or advancement which is expected to have a major impact on the progress of any materiale-related field.

\section{NATURE}

Each Medal will consist of a $\$ 1,000$ cash prize and an engraved Meda bearing a brief citation. The registration fee will be paid for each Medalist to attend the MRS meeting at which the Medal is presented, and reasonable travel expenses will be reimbursed. Each Medalist will be invited to present a genera-interest talk describing his/her work, to be featured within the structure of the meting.

\section{RULES AND ELIGIBILITY}

Nominations for MRS Medalist awards are open to scientists and engineers who have, in recent years, been responsible for major advances in any materials-related field of research. The impact of their materials research upon the relevant materials field will be a primary consideration in making the awards. Medals may recognize such impact within the larger traditional fields or in the more specialized or developing fields.

A nominee need not be a member of the Materials Reseanch Sociely, and nominees of any national origin or citizenship are eligible. Current members of the MRS Awards Committee and MRS Officers are not eligible. The selection of Medal winners must be approved by the MRS Executive Committee with recommendation from the Awards Committee; the decision of the Executive Committee is final. Medals will not be awarded in absentia except under extraordinary circumstances; a Medal winner must receive his/her Medal in person at an MRS meeting. A Medal will normally be awarded to one individual for a cited achievement. In the event that collabo rators for a single achievement are each found to merit recognition on their own merits, then each may be regarded as a candidate for a Medal and judged by the above criteria.

Medal presentation must be made at an appropriate MRS meeting within 12 months of selection.

\section{ADMINISTRATION}

The Medalist program will be managed by the Medals Subcommittee of the Awards Committee. That subcommittee will be responsible for soliciting and evaluating nominations and recommending the successful nominees to the Executive Committee for final approval.

\section{NOMINATION PAOCEDURE}

A package containing the following is required for nomination for an MRS Medal:

1. A statement by the nominator supporting the candidate's suitability for the award with particular reference to:

- specific research achievement which is proposed for the recognition,

- impact of the achievement within the relevant materials field, and its effect on other sciences, and

innovative and perceptive quality of the candidate's work.

2. Supporting information and documents, e.g., curriculum vitae including a list of the candidate's relevant publications. Copies of important papers relevant to the research achievements may also be included.

3. Letters of support from two established scientists familiar with the nominee's qualifications and area of research. Only two such letters will be accepted with each nomination. Each letter should make specific reference to the three criteria in item 1.

4. A list of supporting documents submitted. The entire nomination package, excluding (p)reprints, should not exceed 10 pages.

A nomination for an MAS Medal remains under consideration for three years, and may be updated by the nominator during that time.

\section{DEADLINE FOR SUBMISSION OF NOMINATIONS}

To be considered for an MRS Medal for 1990, a nomination must be submitted by July 1, 1990 to: John B. Ballance, Executive Director, Materials Research Society, 9800 McKnight Road, Pittsburgh, PA 15237.

\section{OUTSTANDING YOUNG INVESTIGATOR AWARD}

\section{PURPOSE}

To recognize outstanding, intendisclplinary scientific work in materials research by a young scientist or engineer. The awardes must also show exceptional promise as a developing leader in the materlals area.

\section{NATURE}

This annual award consists of a $\$ 1,000$ cash prize and a citation plaque. Reasonable travel expenses to attend the Materials Research Society meeting at which the award is presented and the meeting registration toe will be reimbursed. Each winner will be invited to present a general-interest talk to be featured within the structure of the meeting.

\section{RULES AND ELIGIBILITY}

A nominee must be a young scientist or engineer who has contributed in an outstanding and innovative way to the progress of materials research; the work should have a significant interdisciplinary aspect. The nominee shall not have reached his/her 36th birthday prior to 1 January of the year in which the award is made. A nominee need not be a member of the Materials Research Society, and nominees of any national origin or citizenship are eligible. The awand shall be granted without restriction, except that current members of the MRS Awards Committee and MRS Officers are not eligible.

The selection of the Award winner must be approved by the MRS Executive Committee based upon recommendation of the Awards Committee; the decision of the Executive Committee is final. The Award must be received by the winner in person at an MRS meeting; no award will be made in absentia, except under extraordinary circumstances and at the discretion of the Executive Committee.

\section{ADMINISTRATION}

The Award will be managed by a special Outstanding Young Investigator Award Subcommittee of the Awards Committee. That subcommittee will be responsible for soliciting and evaluating nominations and recommending the successful nominee to the Executive Committee for final approval.

\section{NOMINATION PROCEDURE}

A package containing the following is required for nomination for the award: 1. A statement by the nominator supporting the candidate's suitability for the Award with respect to:

innovative and creative nature of the candidate's work,

- interdisciplinary character of the candidate's work, and

- potential shown by the candidate as a future leader in materiais research.

2. Supporting information and documents, e.g., curriculum vitae including a current publication list. Important papers relevant to the award contribution may also be included.

3. Letters of support from two established scientists familiar with the nominee's qualifications and area of research. Only two such letters will be accepted with each nomination. Each letter should make specific reference to the three criteria in item 1.

4. A list of supporting documents submitted. The entire nomination package, including (p)reprints, should not exceed 10 pages.

A nomination for the Young Investigator Award remains under consideration for three years, so long as the age requirement of the Award is met. The nomination package may be updated by the nominator during that time.

\section{DEADLINE FOR SUBMISSION OF NOMINATIONS}

Nomination packages for the inaugural Outstanding Young Investigator Award, to be presented at the 1991 MRS Spring Meeting, should be submitted by November 1, 1990 to: John B. Ballance, Executive Director, Materials Research Society, 9800 McKnight Road, Pittsburgh, PA 15237. 